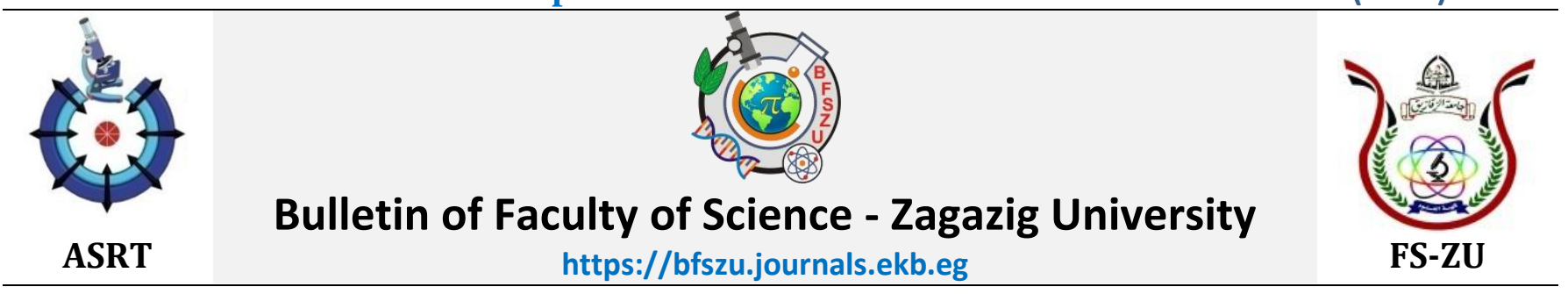

\title{
Evaluation of the Foundation Beds under Construction of New Road Zagazig-Sinbillawain district, East Nile Delta- Egypt, Using Sedimentological and Geotechnical Studies
}

\author{
Samir Mahmoud Zaid ${ }^{1,}$, Ahmed Saad ${ }^{2}$, Ibrahim Lotfy ${ }^{3}$ \\ ${ }^{1}$ Geology Department, Faculty of Science, Zagazig University, Zagazig, Egypt. \\ ${ }^{2}$ Geology Department, Faculty of Science, Al-Azhar University, Cairo, Egypt. \\ ${ }^{3}$ Nile Engineering Consulting Office (N.E.C.B) Nasr City, Egypt
}

\section{ARTICLE HISTORY \\ Received: October/2019 \\ Revised: November/2019 \\ Accepted: December/2019}

\section{KEY WORDS}

Soli

Sediment

Geotechnical Parameters

Bearing Capacity

\begin{abstract}
The present paper is concerned with the study of sedimentological, mineralogical and geotechnical characteristics of the shallow facies and the foundation beds as well as their effects on the construction stability on a planned new road which will extend from El Zagazig to Sinbillawain district. It aims also to introduce some alternative solutions for the impact problems of these shallow facies. The present clay layer has an obvious dangerous effect on the constructions or any other establishments. Thirty one sediment samples from 31 boreholes have been collected at a depth from 0 to $20 \mathrm{~m}$ to investigate the sedimentology, physical, chemical and engineering properties. The results revealed that the initial water content ranges from 30.84 to $44.71 \%$, the liquid Limit (LL) ranges from 51.33 to $71.36 \%$, the plastic Limit (PL) ranges from 20.5 to $36.85 \%$, the shrinkage limit ranges from 11.2 to $20.5 \%$ and the plasticity Index (PI) ranges from 27.78 to $37.17 \%$. The $\mathrm{x}$-ray diffraction analysis revealed that smectite (montmorillonite) and kaolinite minerals are the main components of the clayey sediments. The chemical tests of the studies samples revealed high concentration of sulfates that can increase the corrosion of the concrete foundations. Also the ultimate bearing capacity values are inferred.
\end{abstract}

*Corresponding Author: samir_zaid75@yahoo.com

\section{Introduction}

The study area belongs to eastern part of the Nile Delta.The tectonic and structure framework of the studied area were reported in several works as Said (1962), El Badrawy and Soliman (1997), Shata(1965), 
Shata and El Fayoumy (1970.). the stratigraphy of the studied area discussed by Rizzini, et al (1978), Attia (1954), Said (1981) studied the stratigraphy of the studied area and mentioned that the studied sedimentary succession belongs to the late Pleistocene which is represented by Neonile deposits that accumulated with rate of sedimentation about $1 \mathrm{~m} / 1000$ years. The hydrogeological characteristics in the study area are pointed out by many works as El Dairy (1980), El Fayoumy (1968), Zaghloul, Abd El Daiem, Taha (1990) and Kotb (1988).The Geoelectrical resistivity method at Sharkiya Governorate, Zagazig city, has been applied by El Mahmoudi (1990) using gravity method to reconstruct a framework for the paleohydrography and sedimentological evolution of the eastern Nile Delta

The study area is examined to determine its ability to construct a new road. This road is planned to solve the traffic congestion and reduce the time and distance of transport that lead to reduce economic costs. The proposed new road (about $17 \mathrm{~km}$ long) is a part of the study area which located between longitudes $31^{\circ} 29^{\prime} 15^{\prime \prime}$ to $31^{\circ} 29^{\prime} 10^{\prime \prime} \mathrm{E}$ and latitudes $30^{\circ} 36^{\prime} 3^{\prime \prime}$ to $30^{\circ} 53^{\prime} 48^{\prime \prime} \mathrm{N}$ (Fig.1). Thirty one boreholes were drilled in the study area to represent the construction of suitable sites on this planned road ( 8 bridges and 9 tunnels).

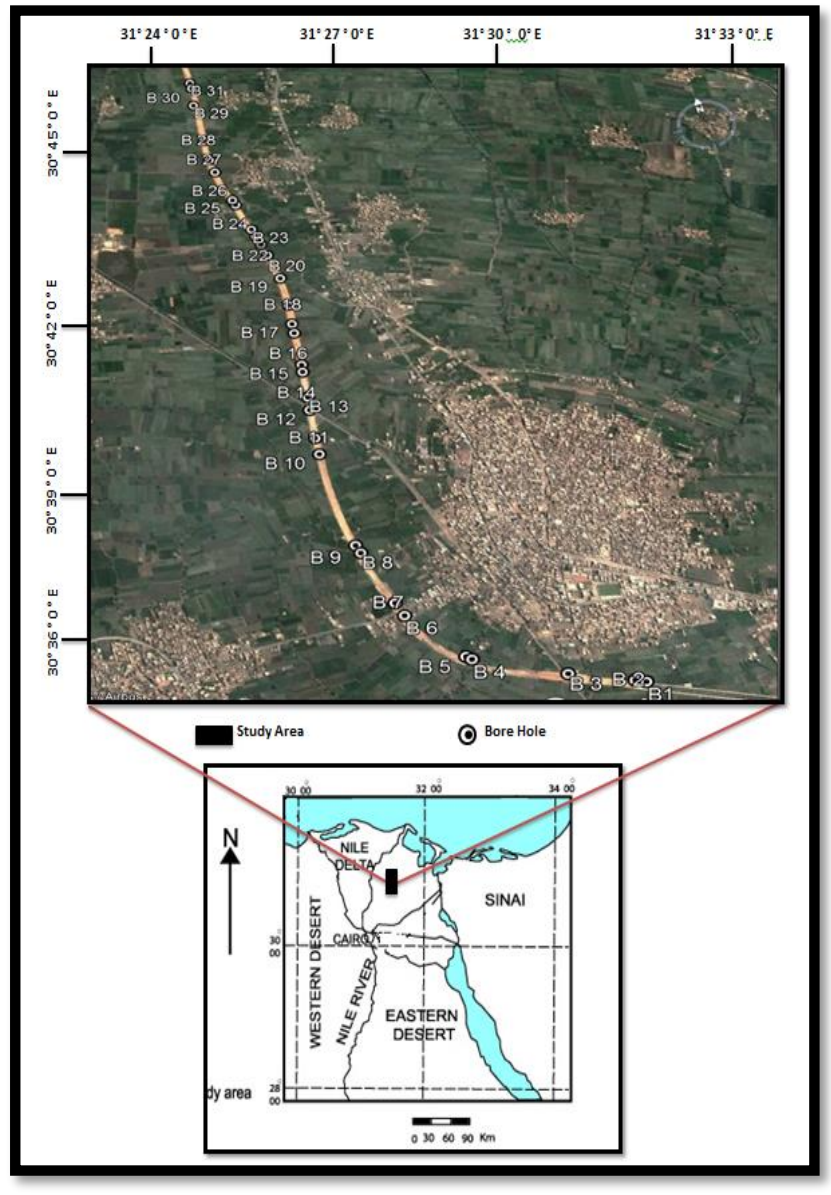

Fig (1): location map of investigated boreholes of study area

\section{Geologic Setting}

The study area is characterized by the low relief and its surface slopes gently towards the north direction and take a rolled shape towards the south direction where the land rises up to a moderately elevated plateau with elevation ranges from 5 to $100 \mathrm{~m}$ (Bayoumy, 1971; Abd El Gawad, 1997). The stratigraphic succession of study area ranges in age from tertiary to quaternary and had a thickness of more than $500 \mathrm{~m}$. The subsurface Tertiary rocks are divided from bottom to top into: Oligocene rocks, Miocene rocks and Pliocene rocks. The subsurface Miocene rocks are subdivided from down to top into Sidi Salem, Qawasim 
and Rosetta formations, while the Pliocene rock units are subdivided from bottom to top into Abu Madi, Kafr EI Sheikh and Wastani formations (Schlumberger, 1984).The Quaternary deposits covered most of the study area and its classified, from bottom to top, into Pleistocene and Recent (Holocene) fig. (2).The rock units which exposed in the area alre mainly related to the quaternary deposits. These deposits represented by Nile silt, Wadi deposits, alluvial fans and sand dunes (GPC and CONOCO, 1987), this illustrated in fig. (3). The sequence is composed of sands, sandy gravels, sandy silt, clay, silt, clay and silt with sand. The sands are coarse to medium grained in size and occasionally cemented by calcareous materials. The lithology description of some boreholes are illustrate in Fig. (4) .The borehole number 3 represent the lithology of tunnels (9 tunnels) with 10 $\mathrm{m}$ depth, while the borehole number 4 represent the lithology of bridges (8 bridges)with $20 \mathrm{~m}$ depth.

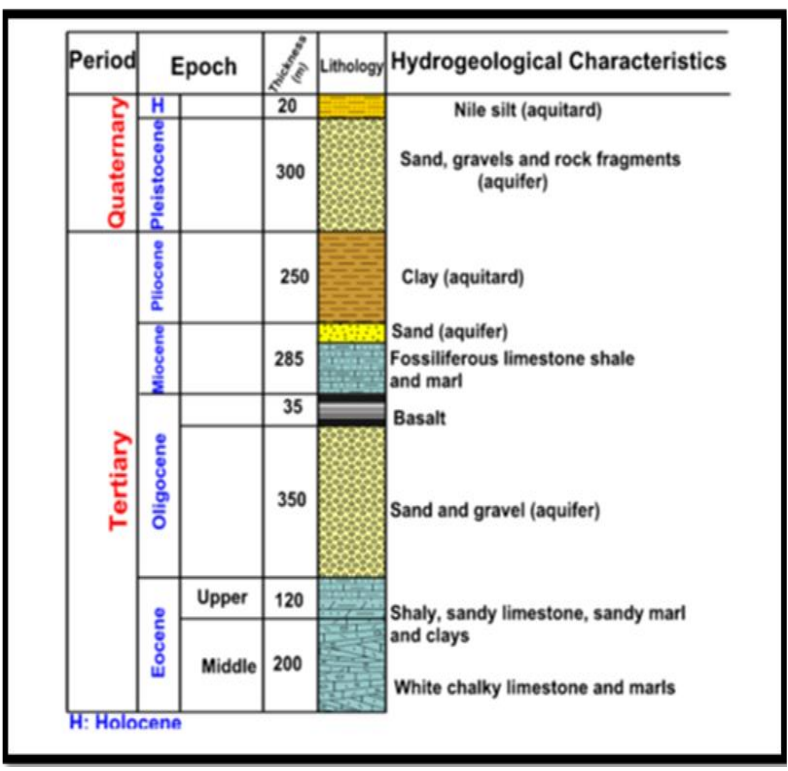

Fig (2): Ideal stratigraphic of exposed section at the studied area, modified after (Schlumberger 1984)

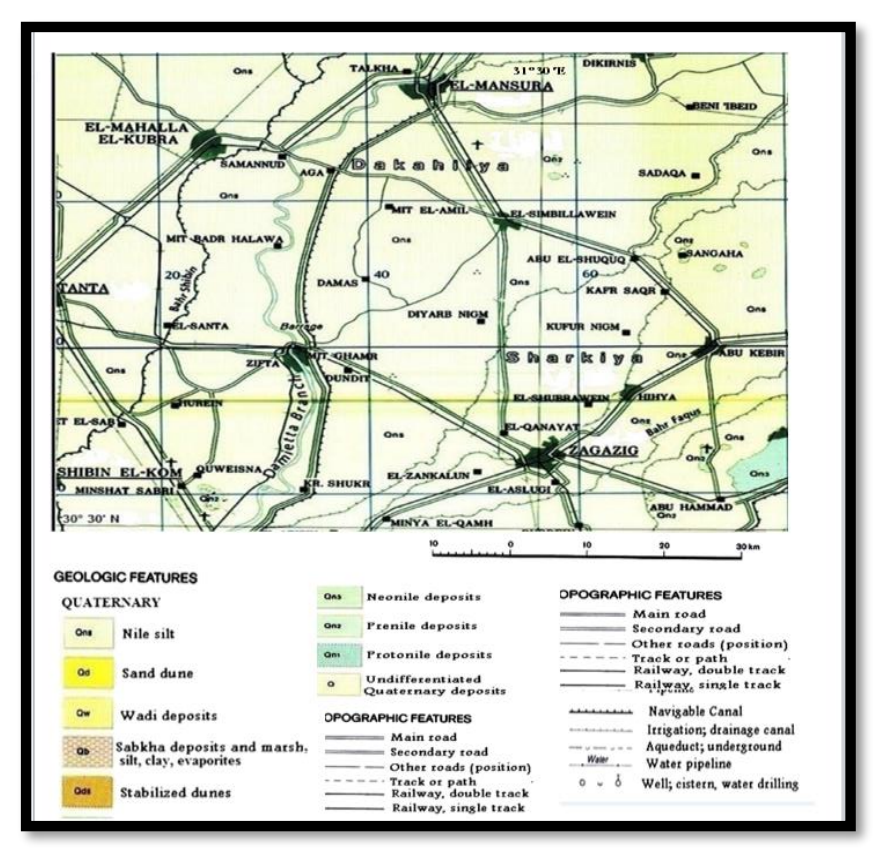

Fig(3) : Geological map of study area (GPC and CONOCO, 1987)

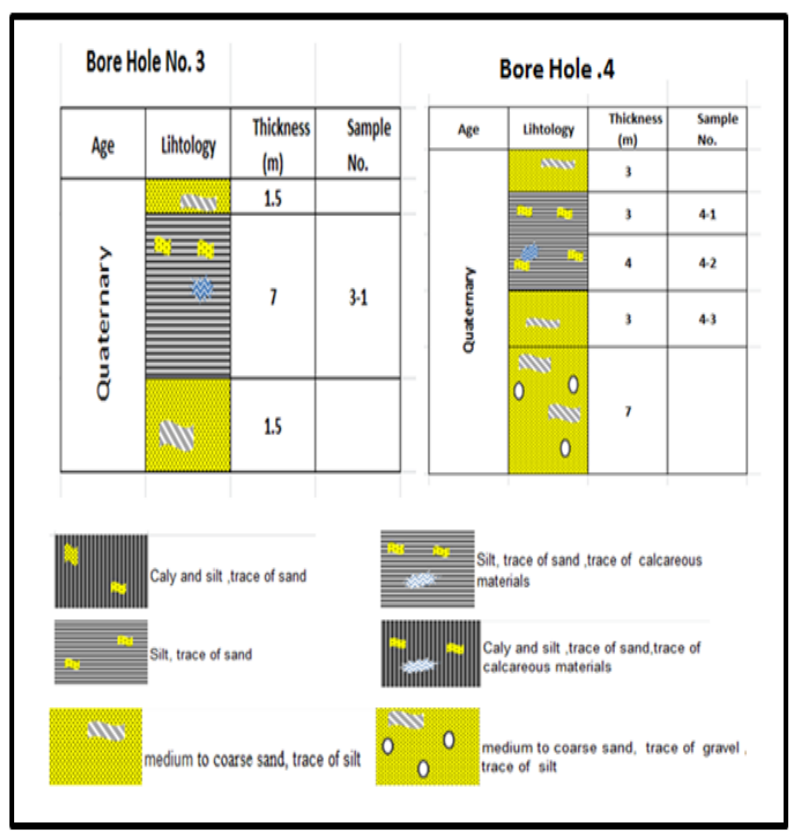

Fig (4): description of the lithology of some borehole log in study area.

\section{Material and Methods}

Thirty one sediment samples from 31 boreholes were collected at a depth from $0 \quad \mathrm{~m}$ to $20 \mathrm{~m}$ to study the physical, chemical, and engineering properties. The current study involves detailed field 
investigations, X-ray analysis for clay minerals, chemical tests and measurements of physical and mechanical parameters such as( sieve analysis, initial water content, atterberg limits, free swelling test, standard penetration test (SPT) and direct shear test).

X-Ray Diffraction analysis of clayey samples was carried out to identify the mineralogical composition. This analysis was carried out on 5 clay fraction samples. The Technique of X-ray analysis carried out by prepared three oriented particle mounts of clay samples as powder shape, then pipetting of this samples suspension on glass slides, one of these mounts was examined by $\mathrm{X}$-ray in its original state (untreated). The second was X-rayed after saturation with ethylene glycol (glycolated) and the third was examined after heating at $550^{\circ} \mathrm{C}$ for two hours (heated). The X-ray diffractograms of oriented samples carried out according to (Moore and Reynolds 1997) and measurements of physical and mechanical parameters such as sieve analysis, Atterberg limits, moisture content, free swelling test, chemical analysis and direct shear box were carried out on the studied samples according to ASTM techniques.

\section{4- $\underline{\underline{\text { Results }}}$}

\section{4-1-Sedimentological Studies}

The investigated sedimentological studies were carried out to differentiate the grain size distribution of the studied samples and calculated the statistical parameters which obtained from grain size analysis.

\subsubsection{Grain Size Analysis}

Grain size analysis required for classifying the sediments into coarse and fine grained soils (ASTM D-422). Hamidi, et al (2012) have explained that in well graded soil the finer particles fill the void formed by coarse particles resulting in a more compacted material and providing more inter locking within the material than in gap graded or uniformly graded soils. Hence a well graded soil is more likely to impart higher shear strength.The results of the mechanical analysis are tabulated in table (1) and the data are represented by histogram and cumulative curve (Figs. 5Aand 5-B). The constructed histogram (Fig. 5) shows the average of the particle size distribution for study sediments and the cumulative curve (Figu.6) shows the textural. The statistical parameters obtained from the grain size analysis are the graphic mean size (Mz), the sorting coefficient ( $\square \mathrm{I})$ and the skewness (SKI). The (MZ) of these samples results ranges from $0.93 \square$ to 2.08 $\square$ and the major samples falling in the (medium sand grade).
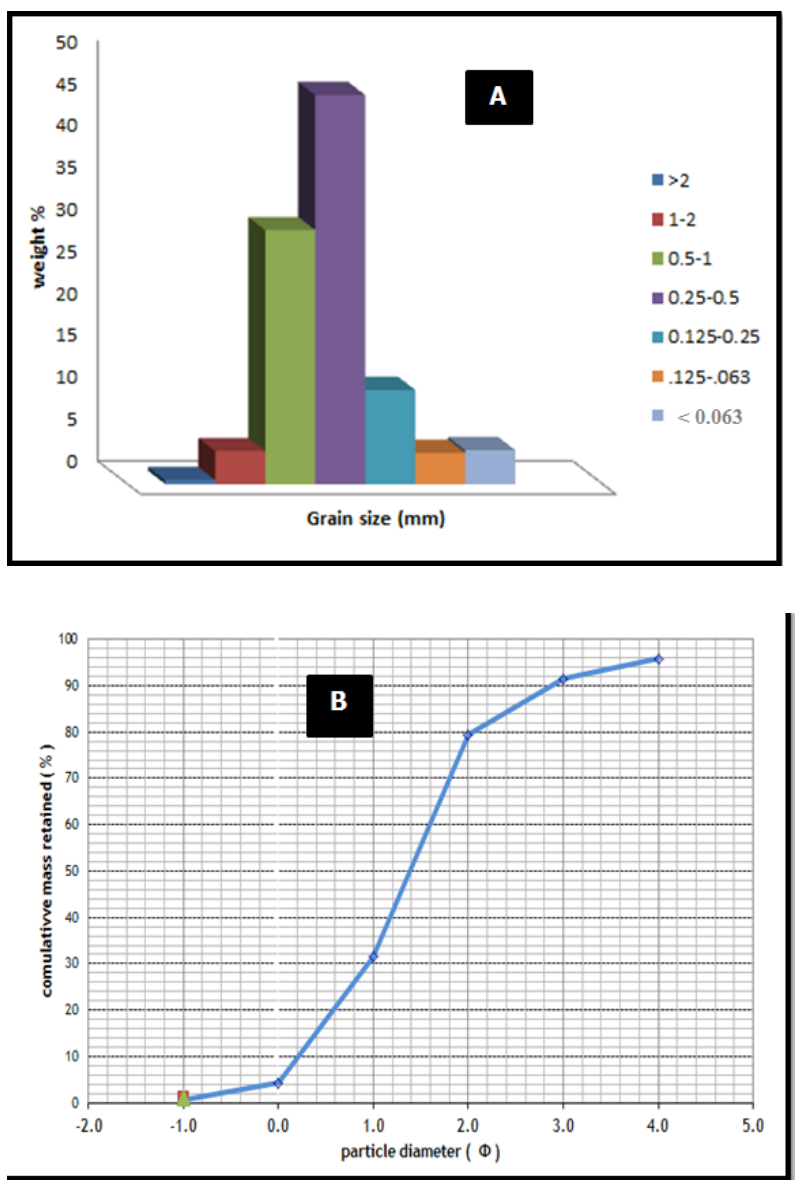

Fig (5): A-Histogram shows the average of the particle size distribution of sand sediments of study area .B-

Cumulative curve of the average of the sand sediments of study area. 
The sorting coefficient ( $\square$ I) ranging from (0.58 to $1.26 \square$ ) and the major samples falling in the moderately sorted, while the value of skewness (SKI) range from (- 0.15 $\square$ to 0.48 ) and the major samples values indicates that the samples are strongly fine to coarse skewed and the kurtosis (KG) ranging from (-0.64. $\square \square$ to 1.22$)$ and the major samples falling in very Platy kurtic.

Table (1): show Average of Grain size data of the studied subsurface samples (31 samples).

\begin{tabular}{|c|c|c|c|c|}
\hline \multicolumn{2}{|c|}{ Grain Size } & Minimum & Maximum & Average \\
\hline \multirow{7}{*}{ Weight $\%$ of fraction } & $>2 \mathrm{~mm}(\mathrm{G})$ & 0 & 8 & 0.48 \\
\hline & 2- $1 \mathrm{~mm}$ (V.c.s) & 0 & 12 & 3.93 \\
\hline & $1-0.5 \mathrm{~mm}$ (C.s) & 12 & 59 & 30.26 \\
\hline & $0.5-0.25 \mathrm{~mm}$ (M.s) & 25 & 68 & 46.33 \\
\hline & $0.25-0.125 \mathrm{~mm}$ (F.s) & 4 & 22 & 11.22 \\
\hline & $0.125-0.063 \mathrm{~mm}$ (V.f.s) & 1 & 7 & 3.72 \\
\hline & $<0.063 \mathrm{~mm}$ (silt + clay) & 1 & 10 & 4.06 \\
\hline \multirow{7}{*}{ Grain size percentiles } & $\phi 5$ & -0.99 & 0.62 & -0.07 \\
\hline & $\$ 16$ & -0.4 & 1.1 & .48 \\
\hline & $\phi 25$ & 0.22 & 1.28 & 0.75 \\
\hline & $\phi 50$ & 0.8 & 1.82 & 1.32 \\
\hline & $\Phi 75$ & 1.5 & 3.20 & 1.9 \\
\hline & $\phi 84$ & 1.8 & 3.40 & 2.27 \\
\hline & $\phi 95$ & 2.8 & 4 & 3.59 \\
\hline \multirow{5}{*}{ Textural parameters } & Mz & 0.93 & 2.08 & 1.36 \\
\hline & $\delta I$ & 0.575 & 1.26 & 0.98 \\
\hline & SkI & -0.15 & 0.48 & 0.15 \\
\hline & KG & -0.64 & 1.22 & 0.78 \\
\hline & KG। & -1.8 & 0.55 & 0.37 \\
\hline
\end{tabular}

Sk1= Inclusive graphic skewness; $\delta \mathbf{I}=$ Inclusive standard deviation; $\mathrm{Mz}=$ Mean size; $\mathrm{KG}=\mathbf{K u r t o s i s}$; G= Gravel V.c.s= Very Coarse sand; C.s= Coarse sand; M.s= Medium sand; F.s= Fine sand; V.f.s= Very fine sand.

\subsection{Mineralogical Studies}

The clay minerals are determined by X-ray diffraction analysis. This analysis was carried out on the clay fraction of five samples which were separated from clay beds. The X-ray diffraction analysis of the selected clay samples revealed that the main clay minerals in the studied samples are montmorillonite and kaolinite (Fig. 6).

\section{2.1. Montmorillonite} mineral in the studied samples forming up to $75 \%$ of the clay mineral content. Montmorillonite is the most common mineral of the smectite group, which has

\subsubsection{Kaolinite}

Kaolinite is the second abundant mineral in the studied clay samples forming up to $25 \%$ of the clay mineral content. important base exchange properties. 


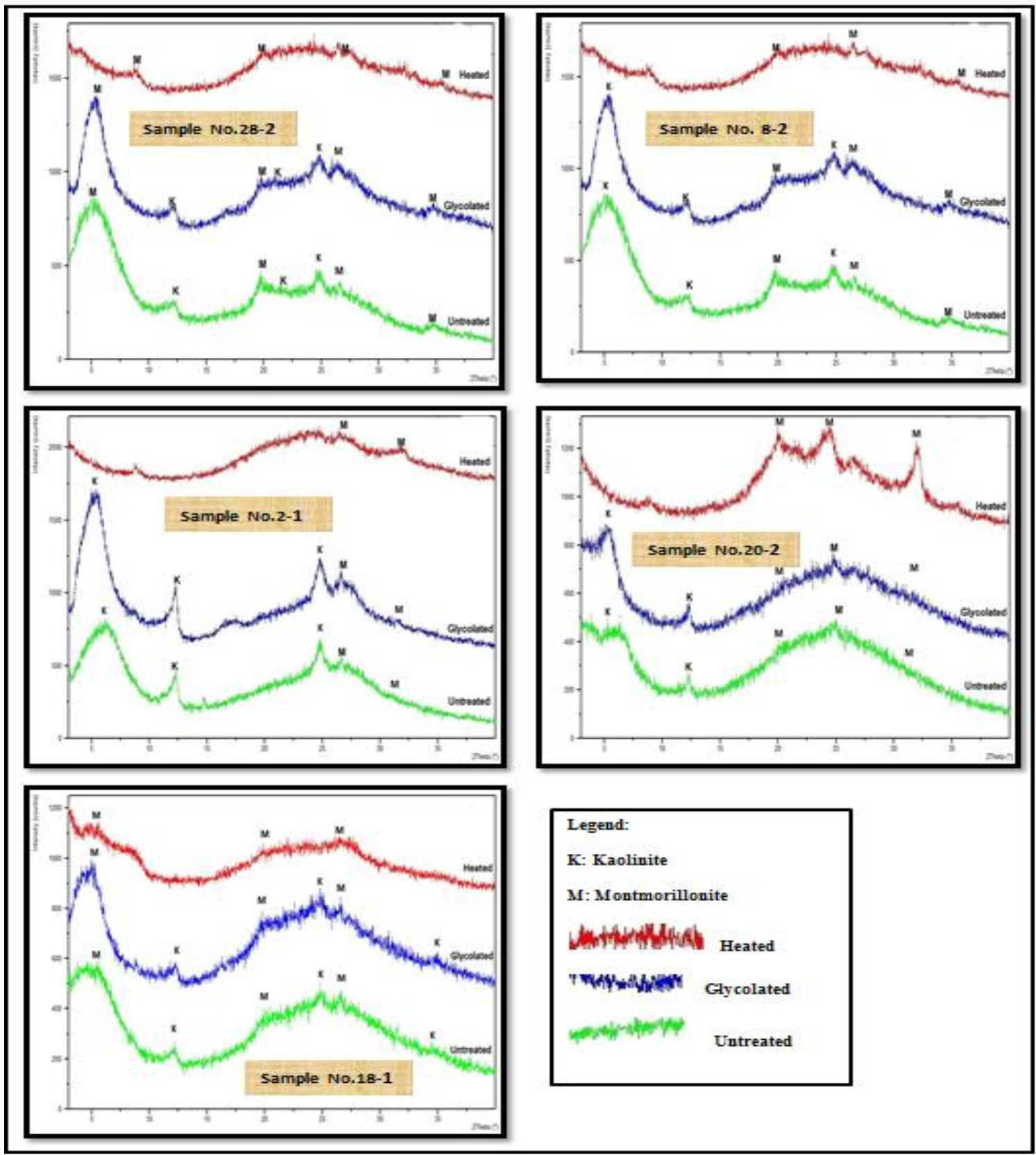

Fig (6): X-ray diffraction of the studied clay fractions.

\subsection{Partial Chemical Tests}

The degree of aggressive for soil can identify through some chemical tests by calculating the concentration of sulphate, chloride, and the $\mathrm{PH}$ values of the soil. These values are occasionally required to confirm the degree of aggressive for soil. The chemical tests data are given in table (3) and the results according to Egyptian code ECP -202/2 table (2) are indicate that the soil characterized by high sulfur concentration $1.51 \mathrm{mg} / \mathrm{l}$ which indicate aggressive nature of the studied soils and lead to enhances the corrosion of concrete foundations. The average of the total dissolved solids (T.D.S) is $477.4 \mathrm{mg} / 1$ which indicate aggressive nature of the studied soils. The average values of the electric resistances (E.C) are $725 \mu \mathrm{S} / \mathrm{cm}$ indicating that the studied 
soils are highly aggressive .However, the chlorides $97.4 \mathrm{mg} / \mathrm{l}$ and $\mathrm{pH} 8$ which indicate to non-aggressive nature of the studied soils.

Table (2):- shows the degree of soil aggressive according to Egyptian code.

\begin{tabular}{|c|c|c|c|c|}
\hline Degree of Aggressive & Non Aggressive & $\begin{array}{c}\text { Moderately } \\
\text { Aggressive }\end{array}$ & Aggressive & Highly Aggressive \\
\hline So $_{3} \%$ & $<0.1 \%$ by weight & $0.1-0.5 \%$ by weight & $0.5 \%-2 \%$ by weight & $>2 \%$ by weight \\
\hline Cl- (P.P.M) & $<300$ P.P.M & $300-1000$ P.P.M & $1000-2000$ P.P.M & $>2000$ P.P.M \\
\hline PH value & $7-8$ & $7-6$ & $6-5$ & $<4.5$ \\
\hline Electric resistance (uS/cm) & $>3000$ & $1500-3000$ & $1000-1500$ & $<100$ \\
\hline
\end{tabular}

Table (3): Results of partial chemical tests of the studied samples

\begin{tabular}{|c|c|c|c|c|c|}
\hline Sample No. & PH & $\begin{array}{c}\text { E.C } \\
\mu \text { S/cm }\end{array}$ & $\begin{array}{c}\text { TDS } \\
\text { ppm }\end{array}$ & $\begin{array}{c}\mathrm{Cl}^{-} \\
\mathrm{ppm}\end{array}$ & So3 \% \\
\hline $2-1$ & 7.9 & 1623 & 1038.7 & 295.66 & 2.19875 \\
\hline $8-2$ & 8.1 & 468 & 299.52 & 64.27 & 0.93098 \\
\hline $11-2$ & 8 & 306 & 195.84 & 20.57 & 0.54345 \\
\hline $13-2$ & 8.1 & 368 & 325.52 & 10.28 & 0.78726 \\
\hline $18-1$ & 8.2 & 505 & 323.2 & 51.42 & 1.412 \\
\hline $20-1$ & 8.1 & 1787 & 1143.7 & 244.24 & 3.631 \\
\hline $25-2$ & 8 & 462 & 295.68 & 30.85 & 0.7655 \\
\hline $28-1$ & 7.8 & 280 & 197.2 & 61.7 & 1.874 \\
\hline Minimum & 7.80 & 280.00 & 195.84 & 10.28 & 0.54 \\
\hline Maximum & 8.20 & 1787.00 & 1143.70 & 295.66 & 3.63 \\
\hline Average & 8.02 & 786.60 & 515.89 & 108.49 & 1.63 \\
\hline
\end{tabular}

\subsection{Geotechnical study}

The geotechnical tests of the studied samples include initial water content, Atterberg limits, free swell, standard penetration test (SPT) and direct shear test.

\subsubsection{Initial Water Content}

When the soil is exposed to a certain amount of load it tends to deform in the direction of the application of the load. The type and value of deformation dependent on the origin of the soil, the structure of the soil particles, and water
content(Ismail and Teshome, 2011). The effect of water content on clay mineral properties are considered in terms of their plasticity ,also change in water content of the soil or rock reducing the strength of soils as collapsible soil and the friction along any discontinuities (McLean, Gribble 1985).The water content determined of studied clay samples according to (ASTM D2216). The values of the water content of studied samples are given in table (4). They range from 30.84 to $44.71 \%$.

\subsubsection{Atterberg Limits and Consistency of Soil}

The Atterberg limits are a term used to describing the consistency of the fine grained soil and is related to a large extent to the water content. This term is defined as the boundaries between four states of soil according to (ASTM D-4318). The soil passes through various states of consistency. These states are liquid, plastic and semisolid states. Liu and Evette (1992) defined the consistency indices as the degree of firmness of the soil, both plastic and liquid limits is consider as important indices which used in the engineering classification of the clays.. The results of the atterberg limit and consistency indices are given in table (4). 
Table (4): The results of water content, Atterberg limits, consistency Indices and free swelling test of the studied clay samples

\begin{tabular}{|c|c|c|c|c|c|c|c|c|}
\hline \multirow{2}{*}{ sample No. } & water content & \multicolumn{3}{|c|}{ Atterberg limits } & \multicolumn{3}{c|}{ consistency indices } & Free Swell \\
\cline { 2 - 9 } & W.C\% & L.L \% & P.L \% & SL \% & P.I \% & L.I\% & CI \% & F.S \% \\
\hline $\mathbf{l - 1}$ & 37.83 & 57.18 & 21.70 & 11.40 & 35.48 & 0.45 & 0.55 & 195.0 \\
\hline $\mathbf{l - 2}$ & 30.84 & 59.33 & 22.16 & 12.10 & 37.17 & 0.23 & 0.77 & 182.0 \\
\hline $\mathbf{2 - 1}$ & 30.93 & 58.29 & 22.18 & 11.50 & 36.11 & 0.24 & 0.76 & 140.0 \\
\hline $\mathbf{3 - 1}$ & 44.6 & 60.51 & 25.20 & 13.50 & 35.31 & 0.55 & 0.52 & 179.0 \\
\hline $\mathbf{4 - 2}$ & 35.15 & 51.33 & 22.90 & 15.50 & 28.43 & 0.43 & 0.99 & 145.0 \\
\hline $\mathbf{7 - 1}$ & 35.48 & 53.38 & 21.14 & 13.50 & 32.24 & 0.44 & 0.56 & 170.0 \\
\hline $\mathbf{8 - 1}$ & 35.74 & 55.42 & 20.50 & 18.50 & 34.92 & 0.44 & 0.56 & 184.0 \\
\hline $\mathbf{1 1 - 1}$ & 34.90 & 61.26 & 28.50 & 14.50 & 32.76 & 0.20 & 0.80 & 198.0 \\
\hline $\mathbf{1 3 - 1}$ & 37.99 & 64.17 & 29.50 & 17.50 & 34.67 & 0.24 & 0.76 & 235.0 \\
\hline $\mathbf{1 5 - 1}$ & 38.16 & 58.90 & 27.80 & 18.00 & 31.10 & 0.33 & 0.67 & 215.0 \\
\hline $\mathbf{1 5 - 2}$ & 41.94 & 65.52 & 31.50 & 13.50 & 34.02 & 0.31 & 0.69 & 242.0 \\
\hline $\mathbf{1 5 - 3}$ & 44.50 & 71.36 & 36.85 & 16.90 & 34.51 & 0.22 & 0.78 & 255.0 \\
\hline $\mathbf{1 6 - 1}$ & 42.76 & 68.2 & 32.44 & 13.00 & 35.76 & 0.29 & 0.71 & 173.0 \\
\hline $\mathbf{1 6 - 2}$ & 36.50 & 59.2 & 28.5 & 12.50 & 30.70 & 0.26 & 0.74 & 152.0 \\
\hline $\mathbf{1 6 - 3}$ & 42.76 & 68.70 & 35.42 & 11.20 & 33.28 & 0.22 & 0.78 & 195.0 \\
\hline $\mathbf{1 7 - 1}$ & 38.75 & 62.15 & 31.37 & 13.00 & 30.78 & 0.24 & 0.76 & 212.0 \\
\hline $\mathbf{1 8 - 1}$ & 44.71 & 68.12 & 34.22 & 14.00 & 33.90 & 0.31 & 0.69 & 195.0 \\
\hline $\mathbf{1 9 - 1}$ & 40.92 & 63.45 & 32.24 & 11.80 & 31.21 & 0.28 & 0.72 & 205.0 \\
\hline $\mathbf{2 0 - 1}$ & 39.84 & 61.94 & 31.72 & 13.70 & 30.22 & 0.27 & 0.73 & 198.0 \\
\hline $\mathbf{2 1 - 1}$ & 40.54 & 61.14 & 31.55 & 12.00 & 29.59 & 0.30 & 0.70 & 200.0 \\
\hline $\mathbf{2 2 - 1}$ & 36.08 & 60.72 & 30.84 & 12.40 & 29.88 & 0.18 & 0.82 & 209.0 \\
\hline $\mathbf{2 3 - 1}$ & 40.33 & 65.20 & 33.51 & 13.00 & 31.69 & 0.22 & 0.78 & 215.0 \\
\hline $\mathbf{2 4 - 1}$ & 38.97 & 68.40 & 32.19 & 12.50 & 36.21 & 0.19 & 0.81 & 245.0 \\
\hline $\mathbf{2 5 - 1}$ & 36.38 & 62.17 & 34.39 & 13.00 & 27.78 & 0.07 & 0.93 & 202.0 \\
\hline $\mathbf{3 0 - 1}$ & 38.17 & 64.32 & 32.43 & 20.50 & 31.89 & 0.18 & 0.98 & 197.0 \\
\hline Minimum & $\mathbf{3 0 . 8 4}$ & $\mathbf{5 1 . 3 3}$ & $\mathbf{2 0 . 5}$ & $\mathbf{1 1 . 2 0}$ & $\mathbf{2 7 . 7 8}$ & $\mathbf{0 . 0 7}$ & $\mathbf{0 . 5 2}$ & $\mathbf{1 4 0}$ \\
\hline Maximum & $\mathbf{4 4 . 7 1}$ & $\mathbf{7 1 . 3 6}$ & $\mathbf{3 6 . 8 5}$ & $\mathbf{2 0 . 5 0}$ & $\mathbf{3 7 . 1 7}$ & $\mathbf{0 . 5 5}$ & $\mathbf{0 . 9 9}$ & $\mathbf{2 5 5}$ \\
\hline Average & $\mathbf{3 8 . 5 3}$ & $\mathbf{6 1 . 9 6}$ & $\mathbf{2 9 . 1 9}$ & $\mathbf{1 4 . 1 0}$ & $\mathbf{3 2 . 7 6}$ & $\mathbf{0 . 2 9}$ & $\mathbf{0 . 7 4}$ & $\mathbf{1 9 7 . 5 2}$ \\
\hline
\end{tabular}

\subsubsection{Liquid Limit (L.L.)}

The liquid limit is defined as the water content corresponding to a limit between liquid and plastic states of consistency. The liquid limit is considered as a tool reflects the type and amount of clay minerals. Snethen, et al (1977) studied seventeen criteria for predicating potential swelling the results of their study indicated that the liquid limit is the best indicator for soil swelling potentiality and used in the soil classification as given in table (5). The liquid limit data of the studied samples range from 51.33 to $71.36 \%$ (table 4), these results indicated that the soil classified as marginal to high swelling potential soils (Snethen, et al. 1977).
Table (5) Potential Swelling classification of soils based on Liquid limits (after Snethen,et al 1977)

\begin{tabular}{|c|c|}
\hline Liquid Limit & Potential Swell Classification \\
\hline$<50$ & Low \\
\hline $\mathbf{5 0 - 6 0}$ & Marginal \\
\hline$>60$ & High \\
\hline
\end{tabular}

\subsubsection{Plastic Limit (P.L.)}

The plastic limit depends on the type and the amount of the clay fraction in the soil and is determined for the part of soil passing from sieve No. 40 $(425 \mu \mathrm{m})$ of studied samples (ASTM D4318). The results of the plastic limit of the studied samples range from 20.5 to $36.85 \%$ (table 4).

\subsubsection{Shrinkage Limit (S.L.)}


According to Arora (1988), the shrinkage limit is defined as the lowest water content at which the soil can still be saturated. The shrinkage limit data of the studied samples range from 11.2 to $20.5 \%$ (table 4).

\subsubsection{Plasticity Index (PI)}

The plasticity index defined as the numerical difference between the liquid limit and plastic limit and describes the ability of a soil to undergo an unrecoverable deformation at constant volume without crumbling; this property indicates the presence of clay minerals (Craig, 1982) as table (6). If the plasticity index of a soil was greater, it will be the engineering problems associated with using this soil as an engineering material, such as a foundation support for residential building and road sub grade (Joseph, and Bowles (1984).The results of the plasticity index of the studied samples range from 27.78 to $37.17 \%$ (table4) that revealed high plastic nature of these samples.

Table (6) shows the classification of soil types according to plasticity Index (PI).

\begin{tabular}{|c|c|c|}
\hline Plasticity Index (PI) & Soil Plasticity & Soil Type \\
\hline $\mathbf{0}$ & Non-Plastic & Sand \\
\hline$<$ & Low-Plastic & Silt \\
\hline $7-17$ & Medium-Plastic & Silty clay or clay silt \\
\hline$>\mathbf{1 7}$ & High-Plastic & Clay \\
\hline
\end{tabular}

\subsubsection{Liquidity Index (L.I.)}

Liquidity index is used to predict the physical state of the soil at its natural moisture content. The numerical data for this prediction proposed by, Whitlow (1983) is as in table (7). The results of this liquidity index of the studied samples range from 0.07 to $0.55 \%$
(Table 4) and reflect that the liquidity index of soil is plastic state.

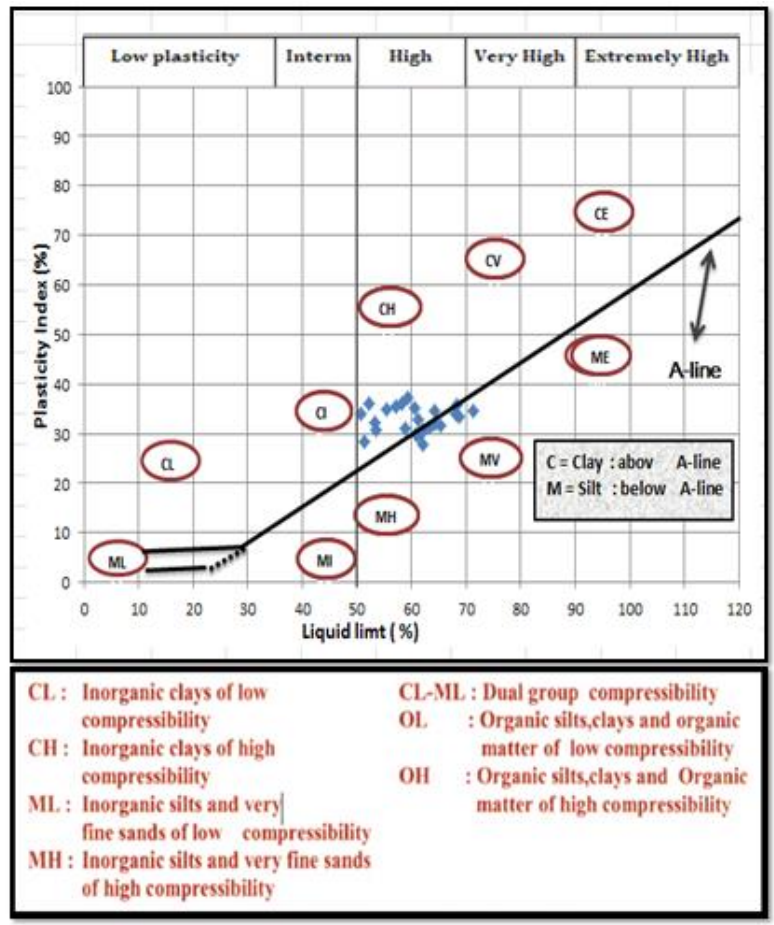

Fig. (7): Classification of the fine-grained soil of the study area by plasticity chart (After Casagrand, 1948).

Table (7) shows the classification of soil types according to Liquidity Index (LI)

\begin{tabular}{|c|c|}
\hline Liquidity Index (LI) & Soil State \\
\hline$<0$ & Semi-Plastic or Solid Stats \\
\hline $0-1$ & Plastic State \\
\hline$>1$ & Liquid State \\
\hline
\end{tabular}

\subsubsection{Consistency Index}

Consistency index defined as the ratio of the difference between the L.L and natural water content to the plasticity index, this index useful in the study of the field behavior of saturated fine grained sediments.Das (.2010) proposed grades of stiffness of soil according to relative consistency as table (8). The results of the consistency index of the studied samples range from 0.52 
to $0.99 \%$ (Table 4) indicating stiff to very stiff grades of the studied soils.

Table (8): Grades of Stiffness of Soil and Relative Consistency.

\begin{tabular}{|c|c|}
\hline Degree of Stiffness & Relative Consistency \\
\hline Very Soft & 0 \\
\hline Soft & $0.01-0.25$ \\
\hline Medium & $0.26-0.50$ \\
\hline Stiff & $0.51-0.75$ \\
\hline Very Stiff & $0.76-1$ \\
\hline Extremely Stiff & $>1$ \\
\hline
\end{tabular}

\subsubsection{Free Swell of the Clayey Soil}

Generally, clay has high swelling characteristics. The free swell test defined as the increase in volume of soil without any external constraint when subjected to submergence in water. It is considered as one of the simplest identifying tests for recognizing the soil expansively (Holtz and Gibbs, 1956). The swelling soils classified according to Egyptian code (ECP -202/2) as table (9). The results of the free swell of the studied samples are illustrated in table (4) and ranges from 140 to $255 \%$, which indicate that the soil characterized by high to extreme swelling properties.

Table (9): Free swell (\%) and its corresponding degree of swelling according to Egyptian code

\begin{tabular}{|c|c|}
\hline Free swell (\%) & Degree of swelling \\
\hline$<\mathbf{3 0}$ & Non \\
\hline $\mathbf{3 0 - 7 0}$ & Weak \\
\hline $70-100$ & Moderate \\
\hline $100-250$ & High \\
\hline$>250$ & Extreme high \\
\hline
\end{tabular}

\subsubsection{Classification of Engineering Properties of Soil}

The engineering classification is used to identify the suitability of the soil for construction uses. The studied soils are classified according to USCS (ASTM D2487) by using the plasticity chart that proposed by Casagrande (1948). In this chart the plotting of the studied data revealed that the major fine grained layers of study area are classified as inorganic clay of high plastic soil and some layer are inorganic silt of high plastic soil.

\subsubsection{Standard Penetration Test (SPT)}

According to (ASTM D-1586) this test is carried out to determine the geo-technical engineering properties of subsurface layers of soil, class of soil and to obtain the penetration resistance or $\mathrm{N}$-value. It is known as the number of blows required to penetrate the soil to a distance of $30 \mathrm{~cm}$ by using weight of $63.5 \mathrm{Kg}$ falling from free height of 76 $\mathrm{cm}$ and carried out in site (not laboratory tests). The obtained N-Value is used to estimate the relative density and angle of internal friction of the in-situ soils table (10) (Meyerhof 1956). The angle of internal friction is used to calculate bearing capacity .The S.P.T values table (11) are being inferred at end of foundation depth $(20 \mathrm{~m})$ of the sandy soil in the representative boreholes of bridges in the study area. The N-values range between $21-46.5$ which elucidate that the state of compaction of the natural soil are range from medium loose to dense and the values of friction angle ranges between $33 \square-40 \square$. 
Table (10): show Correlation between SPT and Angle Internal Friction $\phi\left(^{\circ}\right)$ and relative density for cohesionless soils (Meyerhof 1956).

\begin{tabular}{|c|c|c|c|}
\hline $\begin{array}{c}\text { SPT N3 } \\
{[\text { Blows/30cm-1Ft] }}\end{array}$ & Soil packing & $\begin{array}{c}\text { Relative Density } \\
{[\%]}\end{array}$ & $\begin{array}{c}\text { Friction angle } \\
{[\varphi]}\end{array}$ \\
\hline$<4$ & Very loose sand & $<20$ & $<30$ \\
\hline $4-10$ & Loose sand & $20-40$ & $30-32$ \\
\hline $10-30$ & Compact sand & $40-60$ & $33-36$ \\
\hline $30-50$ & Dense sand & $60-80$ & $36-40$ \\
\hline$>50$ & Very Dense sand & $>80$ & $>40$ \\
\hline
\end{tabular}

Table (11) Results of N-value of the standard penetration test (SPT) at $20 \mathrm{M}$ depth (end of foundation depth )

\begin{tabular}{|c|c|c|c|}
\hline $\begin{array}{c}\text { Borehole } \\
\text { Number }\end{array}$ & $\begin{array}{c}\text { N-Correction } \\
\text { (N/30cm) }\end{array}$ & $\begin{array}{c}\text { Borehole } \\
\text { Number }\end{array}$ & $\begin{array}{c}\text { N-Correction } \\
\text { (N/30cm) }\end{array}$ \\
\hline 1 & 39.5 & 18 & 30 \\
\hline 2 & 40.5 & 19 & 36.5 \\
\hline 4 & 46.5 & 20 & 35 \\
\hline 5 & 39.5 & 21 & 38.5 \\
\hline 6 & 45 & 22 & 39.5 \\
\hline 7 & 40.5 & 23 & 32 \\
\hline 8 & 35 & 27 & 25 \\
\hline 9 & 28 & 28 & 21 \\
\hline 13 & 31.5 & 29 & 31 \\
\hline 14 & 29.5 & 30 & 33 \\
\hline 17 & 25 & 31 & 35 \\
\hline Minimum & & 21 & \\
\hline Maximum & & 46.5 & \\
\hline Average & & 34.35 & \\
\hline
\end{tabular}

\subsubsection{Direct Shear Test}

The direct shear test is a laboratory test which used to measure the shear strength properties of soil.by determines the shear strength parameters $(\mathrm{C}$ and $\varphi$ ). These parameters are determined in the studied sand soils according to (ASTM D 3080). The calculated shear strength parameters (table 12) show that the friction angle $(\varphi)$ of the studied samples range from $33^{\circ}$ to $36^{\circ}$ while the cohesion $\mathrm{C}$ equal to zero for sand sample (Fig. 8).
Table (12): Shear strength parameter of studied sand samples from shear test

\begin{tabular}{|c|c|c|c|c|}
\hline $\begin{array}{l}\text { Sample } \\
\text { No. }\end{array}$ & $\begin{array}{l}\text { Normal Stress } \\
\left(\mathrm{Kg} / / \mathrm{cm}^{2}\right)\end{array}$ & $\begin{array}{c}\text { Shear Stress } \\
\left(\mathrm{Kg} / / \mathrm{cm}^{2}\right)\end{array}$ & $\begin{array}{l}\text { Friction Angel } \\
(\Phi)\end{array}$ & $\begin{array}{l}\text { Cohesion } \\
\text { c ( KG ) }\end{array}$ \\
\hline \multirow{3}{*}{$4-3$} & 1 & 0.47 & \multirow{3}{*}{33} & \multirow{3}{*}{0.0} \\
\hline & 2 & 1.01 & & \\
\hline & 3 & 1.47 & & \\
\hline \multirow{3}{*}{$13-2$} & 1 & 0.88 & \multirow{3}{*}{33} & \multirow{3}{*}{0.0} \\
\hline & 2 & 1.41 & & \\
\hline & 3 & 2.22 & & \\
\hline \multirow{3}{*}{ 23-2 } & 1 & 0.79 & \multirow{3}{*}{34} & \multirow{3}{*}{0.0} \\
\hline & 2 & 1.25 & & \\
\hline & 3 & 2.19 & & \\
\hline \multirow{3}{*}{$27-2$} & 1 & 0.72 & \multirow{3}{*}{36} & \multirow{3}{*}{0.0} \\
\hline & 2 & 1.66 & & \\
\hline & 3 & 2.41 & & \\
\hline \multirow{3}{*}{$31-2$} & 1 & 0.81 & \multirow{3}{*}{36} & \multirow{3}{*}{0.0} \\
\hline & 2 & 1.67 & & \\
\hline & 3 & 2.48 & & \\
\hline Minimum & & & 33 & \\
\hline Maximum & & & 36 & \\
\hline Average & & & 34.4 & \\
\hline
\end{tabular}

\subsubsection{Bearing Capacities}

The bearing capacity is the ability of the foundation material, weather soil or rock to carry loads safety without shear (Terzaghi, 1943). In the study area there are two types of foundations, shallow foundations represented by surface tunnels above the ground and deep foundation represented by bridges. The deep foundations are supported by piles and loaded in sand bed with diameter $1 \mathrm{~m}$ and area $0.785 \mathrm{~m}^{2}$ at depth $20 \mathrm{~m}$. The values of allowable 
ultimate bearing capacity range from 210 ton to 465 ton at $20 \mathrm{~m}$ depth. These values (table 13) are illustrated in distribution map (Fig. 9) and indicate that the soil bearing capacity increases with increasing of S.P.T values, depth of foundation, cohesion and internal friction angle.
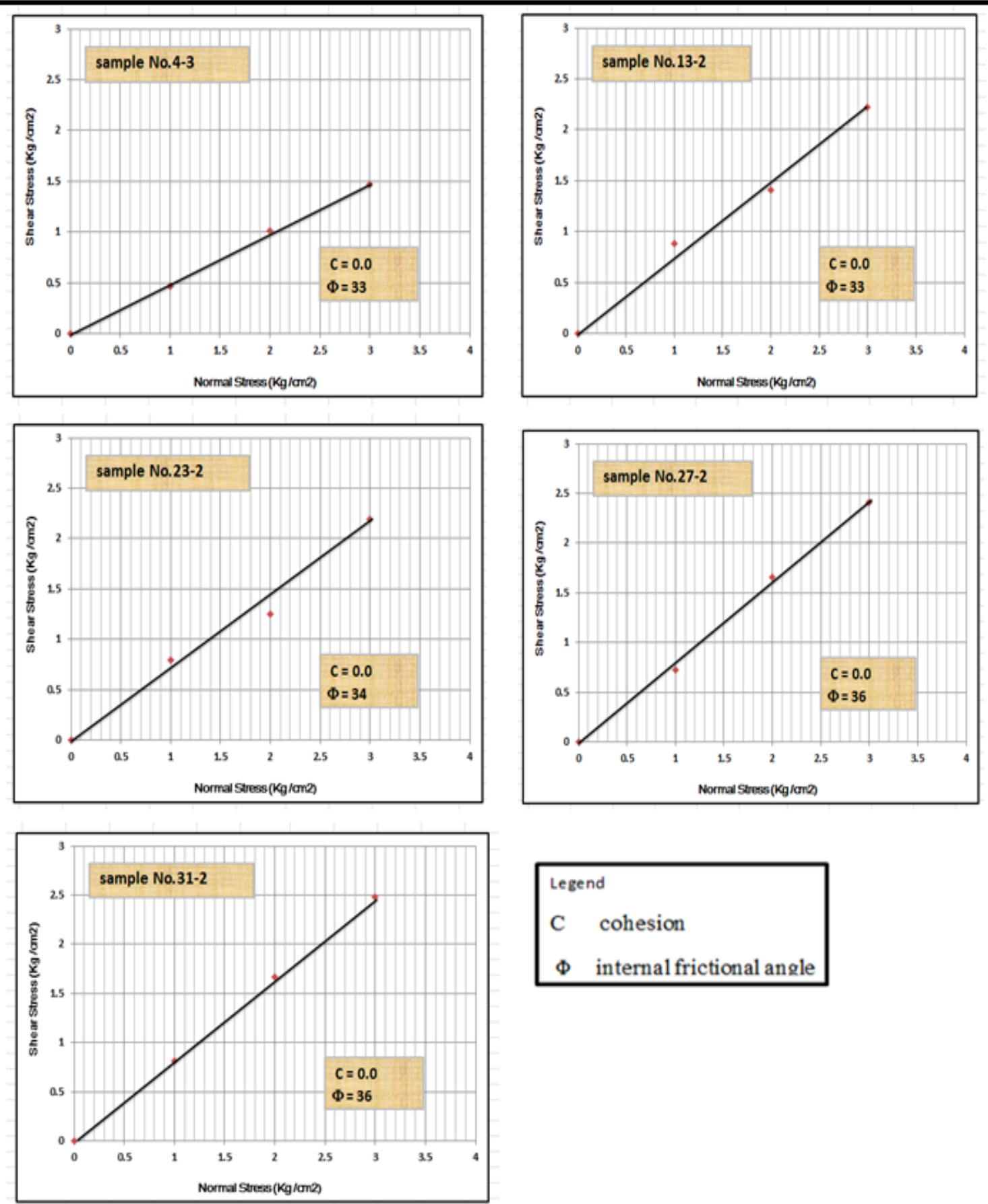

Fig. (8): Shear Stress Versus Normal Stress of studied sand Samples 
Table (13): The values of allowable ultimate bearing capacity

\begin{tabular}{|c|c|c|c|}
\hline $\begin{array}{l}\text { Borehole } \\
\text { Number }\end{array}$ & $\begin{array}{c}\mathrm{Qa} \\
\text { Ton/m2 }\end{array}$ & $\begin{array}{l}\text { Borehole } \\
\text { Number }\end{array}$ & $\begin{array}{c}\text { Qa } \\
\text { Ton/m2 }\end{array}$ \\
\hline 1 & 370 & 18 & 300 \\
\hline 2 & 405 & 19 & 365 \\
\hline 4 & 465 & 20 & 350 \\
\hline 5 & 395 & 21 & 385 \\
\hline 6 & 450 & 22 & 395 \\
\hline 7 & 405 & 23 & 320 \\
\hline 8 & 350 & 27 & 250 \\
\hline 9 & 460 & 28 & 210 \\
\hline 13 & 315 & 29 & 310 \\
\hline 14 & 318 & 30 & 330 \\
\hline 17 & 250 & 31 & 350 \\
\hline \multicolumn{2}{|c|}{ Minimum } & \multicolumn{2}{|c|}{210} \\
\hline \multicolumn{2}{|c|}{ Maximum } & \multicolumn{2}{|c|}{456} \\
\hline \multicolumn{2}{|c|}{ Average } & \multicolumn{2}{|c|}{351} \\
\hline
\end{tabular}

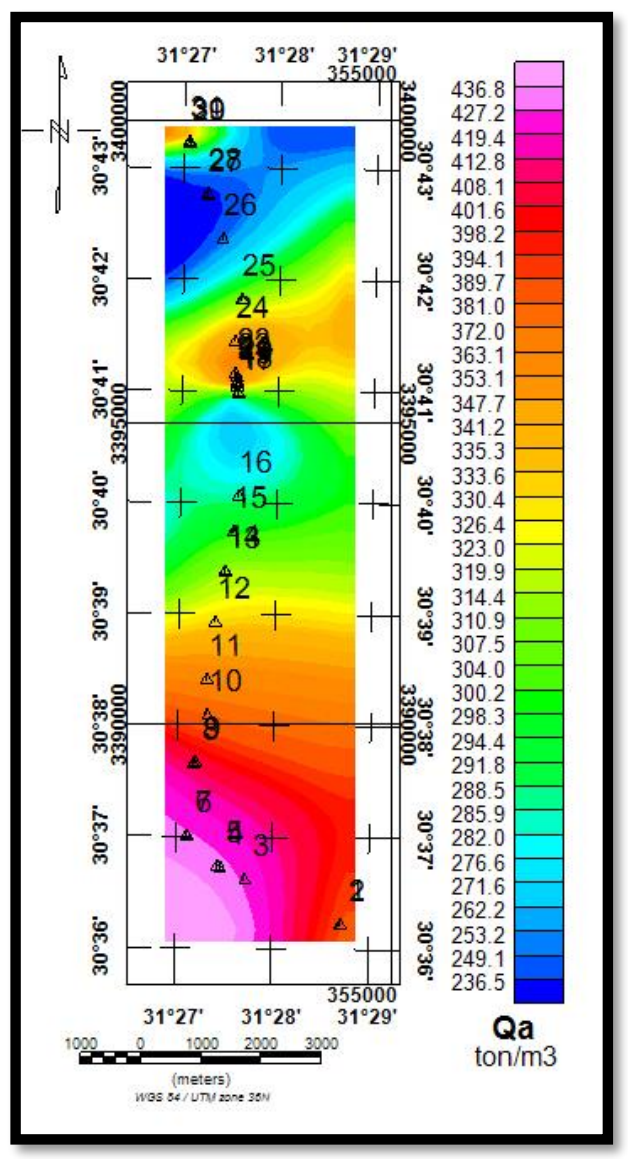

Fig. (9): distribution maps of the values of the ultimate bearing capacity

\section{Conclusion}

The present works dealt with the sedimentological, mineralogical and the geotechnical properties of the foundation beds and locate the risk zones that may take place on the foundation beds during the construction of the new road from El Zagazig to Sinbillawain district. The studies were carried out through thirty one sediment samples collected from 31 boreholes $\mathrm{n}$ at a depth from $0 \mathrm{~m}$ to $20 \mathrm{~m}$.

From sedimentological studies the grain size analysis illustrated that, the sediments are of medium sand grade, moderately sorted. The histograms show that almost samples have bimodal distribution types with medium to fine sand size grades. The distribution curves are generally indicated that the studied soils are good foundation sediment.

The mineralogical study of clay fractions indicate that montmorillonite is the most predominant mineral in the studied samples forming up to $75 \%$ of the clay mineral content, while kaolinite is the second abundant mineral in the studied clay samples up to $25 \%$ of the clay content

The chemical test of the investigated sediments shows that these sediments have high content of sulfates $(1.51 \mathrm{mg} / \mathrm{l})$, which may play role for the corrosion of the concrete foundations. The averages of the total dissolved solids (T.D.S) are $(477.4 \mathrm{mg} / \mathrm{l})$ indicate an aggressive nature of the studied soils. The average of electric resistances (E.C) values $(725 \mu \mathrm{S} / \mathrm{cm})$ reflects a highly aggressive nature. However the average chlorides is (97.4 mg/l) and $\mathrm{pH}$ is (8) reflect a non-aggressive nature of the studied soils

The geotechnical tests of studies soil samples revealed that, the clayey 
soils have high liquid limit ranges between (51.33-71.36\%) compared to their relatively low plastic limit (20.5$36.85 \%)$ with plasticity index (27.7$37.17 \%)$. In addition, the clay samples are swelled and may be further supported by the low values of shrinkage limit (11.2-20.5 \%) with high free swelling (140-250\%). The direct shear box data of the studied samples pointed out that the cohesion equal to zero in all sample, while the values of friction angle range from $32^{\circ}$ to $36^{\circ}$. The direct shear parameters reveals that the ultimate soil bearing capacity values of the studied samples are range from 210 ton to 465 ton at the end of the founding depth (20 $\mathrm{m})$. Distribution map of ultimate soil bearing capacity shows that the highest values of ultimate soil bearing capacity are recorded at the southern parts of the study area, while the lowest values are calculated in the northern part of the study area. This meaning that the foundation beds at the southern part can carry heavy loads more than that at the northern part.

\section{Recommendations}

The results of the present sedimentological, mineralogical and geotechnical studies conclude that the extreme clay layer of the study area exhibits low quality materials and cannot be used for any construction because of its high swelling property, which has a dangerous effect on the constructions. If it is necessary to use this type of soil for shallow constructions such as surface tunnel above the ground, this soil must be removed and replaced by another clean sand soil come from another place to be distributed under the foundation. This new layer should not be less than 2 $m$ thick. In another hand when use this kind of clayey sediments in the study area for deep foundation, such as bridges, the soil layer should be reinforced by the traditional means such as piles

\section{References}

Abd El Gawad, A.M., Shallow geophysical exploration for defining the water occurrences in the area east of the Nile Delta, Egypt. Ph.D.Fac. Sci. Ain Shams Univ., Cairo, Egypt, 1997.

Arora, K.P., Introductory soil engineering, new chandJain, Delhi, India, 630 p, 1988.

ASTM, Annual Book of ASTM Standards .Standard Test Method for direct shear test of soil under UN consolidation- drained condition.D3080.1994.

ASTM, Annual Book of ASTM Standards. Standard Test Method for Classification of Soils for Engineering Purposes (Unified Soil Classification System). D2487. 2006.

ASTM., Annual Book of ASTM Standards .Standard Test Method for Liquid Limit, Plastic Limit and Plasticity Index of Soils, , D4318, 2010.

ASTM., Annual book of ASTM standard .Standard Test Method for Particle-Size Analysis of Soils, Annual Book of ASTM Standards, D422, 2007.

ASTM., Annual Book of ASTM Standards .Standard .Test Method for Standard Penetration Test (SPT) and Split-Barrel Sampling of Soils. D1586. 2011.

ASTM, Annual Book of ASTM Standards .Standard Test Method for Laboratory Determination of Water Content of Soil.D2216

Attia, M.I., Deposits in the Nile Valley and the Delta. Geological. Surv., Egypt Government press, Cairo. 1- 356.1954. 
Bayoumy, M.R., Pedological studies on agricultural expansion areas west of the Suez Canal. M.Sc. Thesis, Fac. Agric., Cairo Univ., Egypt, 85p.1971.

Casagrande, A., Classification and identification of soils Am. Soc. Civ. Civ. Eng. Trans. Vol., 113, pp. 901-930.1948.

CONOCO, GPC and CONOCO .Geological map of Egypt. Map scale 1:500.000.1987.

Craig, R.F.,Soil mechanics 5th edition, Chapman and Hall, British, p. 427.1982.

Das B.M. Principles of geotechnical engineering, seven editions, Cengage Learning, USA. 666 P, 2010.

ECP -202/2., The Egyptian code of soil mechanics for designing and accomplishing the foundations. Part (2), Laboratory Tests, HBRC, Egypt, pp. 98103.2011.

El Badrawy and Soliman. Evaluation of subsurface active structures of $\mathrm{El}$ Asher of Ramadan area, Using gravity, aeromagentic and seismic data. J Geol., Egypt: 817- 837.1997.

El Dairy, M., Hydrogeological studies on the eastern part of Nile Delta, Using isotope technique. M.Sc. Thesis, Fac. Sci., El-Azhar Univ., Egypt: 1246.1980.

El Fayoumy, I.F., Geology of groundwater supplies in the region east of the Nile Delta. Ph. D. Thesis, Fac. Sci., Cairo Univ., Egypt, 207p.1968.

El Mahmoudi, A.E., et al., Geophysical implications in environmental geology for development of the eastern Nile Delta. In: A.R.E. Geophys. Proc. of $3^{\text {rd }}$ Scient. Gen. Meeting, NRIAG. pp. 117125.1990.

Hamidi, et al. Impact of gradation on the shear strength-dilation behavior of well graded sand-gravel mixtures, Scientia Iranica, 19(3): 393- 02.2012.
Holtz, W. G. and Gibbs, H. J., Engineering properties of expansive clays: Transactions, ASCE 121, 641677. 1956.

Ismail A. and Teshome F., Analysis of deformations in soft clay due to unloading, MSc. Thesis., CHALMERS. Uni. Göteborg, Sweden.2011.

Joseph E. Bowles., Physical and geotechnical properties of soils; McGraw-Hill, International Book Company, London, $2^{\text {nd }}$ ed.; p. 578.1984.

Kotb, A. M., Geological, Hydrogeological And Geoelectrical Studies on The Eastern Portion of Delta, M. Sc. Thesis, Fac. of Sci., Al- Azhar university., Cairo, Egypt,126p". 1988.

Liu, C. and Evette, J.B., Soil and foundation 3rd edition, Prentice Hall, New Jersy, 465p.1992

McLean A.C. and Gribble C.D. geology for civil engineer, sec. edition, University of Glasgow, London, UK. 334 P. 1985.

Meyerhof, G.G., Penetration Test and Bearing Capacity of Cohesionless Soils, Journal of the Soil Mechanics and Foundation Division, ASCE, Vol.82, No. SM1, pp. 1.1956.

Meyerhof, G. G., Some Recent Research on the Bearing Capacity of Foundations. Canadian Geotechnical Journal, Vol. 1, 16-26.1976.

Moore.D.M and Jr. Reynolds.C.R., "X-ray diffraction and the identification and analysis of clay minerals", New York (Oxford University Press), 332 p.1997.

Rizzini, A., et al. Stratigraphy and sedimentation of Neogene-Quaternary section in the Nile Delta area. (A.R.E.) Mar-Geol., V27, pp. 327-348.1978. 
Said (The geology of Egypt) the structural setting of the area of the Nile Delta. Elsevier, New York, 377 p, 1962.

Said. The geological evolution of the Nile River", Springer Verlag, New Work, 1981, 151 p .1981

Schlumberger. Well evaluation conference, Egypt. Schlumberger, Middle East, S.A.1984.

Shata, A.A., Geological structure of the Nile Delta. J. of Eng. Cairo, (in Arabic), 1-3.1965.

Shata, A.A. and Fayoumy.I.F. Remarks on the regional geological structure of the Nile Delta. Symposium Hydrology of Delta, UNESCO, I: 189197.1970.

Snethen, D.R., et al. An evaluation of expedient methodology for identification of potentially expensive soils. Sponsored by the federal highway administration and department of transportation, pp.48.1977.

Terzaghi, K., Theoretical soil mechanics, John Weller and sons, Inc. London. 500 P. 1943.

Whitlow, R., Basic soil mechanics. Longman Croup Limited, New York pp. 439.1983.

Zaghloul, Z.M.; Abd El Daiem, A.M. and Taha, A.A., Geomorphology, Geologic evolution and subsidence of the Nile Delta during the Quaternary. Bull. Fac. Sci., Mansoura univ., V.17, No.1, pp. 471-495.1990. 